\title{
PENGARUH LIKUIDITAS, UKURAN PERUSAHAAN, LEVERAGE TERHADAP PROFITABILITAS DENGAN CORPORATE SOCIAL RESPONSIBILITY SEBAGAI VARIABEL INTERVENING PADA PERUSAHAAN CONSUMER GOODS YANG TERDAFTAR DI BURSA EFEK INDONESIA
}

\section{Hantono, Teng Sauh Hwee}

Faculty of Economic, Departement of Accounting, Universitas Prima Indonesia

\author{
A R T IC LE INFO
}

Keywords : liquidity, Firm Size, Leverage, Profitability amd Corporate Social Responsibility

Kata Kunci : Likuiditas, Ukuran Perusahaan, leverage, Profitabilitas dan Tanggung Jawab Sosial Perusahaan.

Corresponding author :

Hantono

hantono_78@yahoo.com
Abstract : This study aims to demonstrate and analyze the influence of financial ratios towards profitability by disclosure of corporate social responsibility on the consumer goods company that SKPLBI in 2011-2015 year Indonesia stock exchange. The population in this research is the 39 companies consumer goods SKPLBI Indonesia stock exchange in the years 2011-2015. Of the 39 companies that SKPLBI, selected 19 sample corporate by using purposive sampling. The results of the discussion indicates that simultaneous independent variables; Current ratio, Company Size, leverage and profitability with the F test, together have an effect on corporate social responsibility. Partial results with $t$ test, variable current ratio, a measure of Corporate Profitability, leverage and influence on corporate social responsibility.

Abstrak : Penelitian ini bertujuan untuk membuktikan dan menganalisis pengaruh rasio keuangan terhadap profitabilitas dengan pengungkapan Corporate Social Responsibility pada perusahaan consumer goods yang terdaftar di Bursa Efek Indonesia tahun 2011-2015. Populasi dalam penelitian ini adalah 39 perusahaan consumer goods yang terdaftar di Bursa Efek Indonesia tahun 2011-2015. Dari 39 perusahaan yang terdaftar, dipilih 19 perusahaan sampel dengan menggunakan purposive sampling. .Hasil pembahasan menunjukkan bahwa secara simultan variabel-variabel independen; Current Ratio,Ukuran Perusahaan, leverage dan Profitabilitas dengan uji F, secara bersama-sama berpengaruh terhadap Corporate Social Responsibility. Hasil secara parsial dengan uji t, variabel Current Ratio,Ukuran Perusahaan, leverage dan Profitabilitas berpengaruh terhadap Corporate Social Responsibility. 


\section{Latar Belakang}

\section{PENDAHULUAN}

Pada dasarnya, setiap perusahaan memiliki tujuan utama yaitu untuk memperoleh laba yang maksimal. Pada era globalisasi ini, persaingan antar perusahaan yang semakin ketat, menuntut perusahaan untuk menghadapi dan mengantisipasi segala situasi agar mampu bertahan dan tetap maju di tengah situasi perekonomian Indonesia yang sedang memburuk, khususnya dalam rangka pencapaian tujuan utama perusahaan tersebut.

Undang-Undang Nomor 40 Tahun 2007 tentang Perseroan Terbatas memberikan definisi mengenai tanggung jawab sosial perusahaan. Tanggung jawab sosial dan Lingkungan merupakan komitmen Perseroan untuk ikut berperan dalam pembangunan ekonomi yang berkelanjutan guna meningkatkan kualitas kehidupan dan lingkungan yang bermanfaat, baik bagi Perseroan sendiri, komunitas setempat maupun masyarakat pada umumnya. Di Indonesia, Undang-Undang Nomor 40 Tahun 2007 tentang Perseroan Terbatas menjadi pedoman bagi perusahaan melakukan kegiatan CSR.

CSR dilakukan sebagai upaya untuk mendapatkan manfaat jangka panjang bagi perusahaan berupa kepercayaan dan loyalitas konsumen. Masih banyak perusahaan yang tidak menjalankan program CSR, karena melihat hal tersebut hanya sebagai pengeluaran biaya. CSR tidak memberikan hasil secara keuangan dalam jangka pendek, namun langsung memberikan hasil baik langsung maupun tidak langsung pada keuangan perusahaan di masa mendatang.

Tanggung jawab sosial perusahaan atau corporate social responsibility digunakan sebagai ketersediaan informasi keuangan dan non keuangan berkaitan dengan interaksi organisasi dengan lingkungan fisik dan lingkungan sosialnya yang dapat dibuat dalam laporan tahunan perusahaan atau laporan sosial terpisah (Guthrie dan Athews 1985 dalam Rakhiemah dan Agustia, 2009).

Perusahaan yang memiliki leverage yang tinggi berarti memiliki hutang yang lebih besar dibandingkan dengan modal. Jika terjadi peningkatan laba, maka yang diuntungkan adalah pemberi hutang atau kreditur, sehingga semakin baik kondisi laba perusahaan maka semakin negatif respon pemegang saham, karena pemegang saham beranggapan bahwa laba tersebut hanya menguntungkan kreditur (Rofika, 2015). Penelitian Rahman et al. (2011), Giannarakis (2014) serta penelitian Habbash (2015) menemukan adanya pengaruh negatif antara leverage dengan luas pengungkapan CSR.

Berdasarkan latar belakang di atas, maka perumusan masalah sebagai berikut:

1. Bagaimana pengaruh likuiditas terhadap pengungkapan corporate social responsibility?

2. Bagaimana pengaruh modal kerja terhadap pengungkapan corporate social responsibility?

3. Bagaimana pengaruh ukuran perusahaan terhadap pengungkapan corporate social responsibility?

4. Bagaimana pengaruh leverage terhadap pengungkapan corporate social responsibility?

5. Bagaimana pengaruh likuiditas, modal kerja, ukuran perusahaan dan leverage terhadap pengungkapan corporate social responsibility?

\section{TINJAUAN PUSTAKA}

\section{Likuiditas}

Menurut Harahap (2013:301), rasio likuiditas menggambarkan kemampuan perusahaan untuk menyelesaikan kewajiban jangka pendeknya. Rasio-rasio ini dapat dihitung melalui sumber informasi tentang modal kerja yaitu pos-pos aktiva lancar dan utang lancar.

Menurut Murhadi (2013:57), rasio likuiditas adalah rasio yang menunjukkan kemampuan perusahaan dalam memenuhi liabilitas jangka pendeknya.

Menurut Kasmir (2014:130), rasio likuiditas sering disebut dengan nama rasio modal kerja merupakan rasio yang digunakan untuk mengukur seberapa likuidnya suatu perusahaan. Terdapat dua hasil penilaian terhadap pengukuran rasio likuiditas, yaitu apabila perusahaan mampu memenuhi kewajibannya, dikatakan perusahaan tersebut dalam keadaan likuid. Sebaliknya, apabila perusahaan tidak mampu memenuhi kewajiban tersebut, dikatakan perusahaan dalam keadaan illiquid.

Menurut Hanafi dan Halim (2014:75), rasio likuiditas mengukur kemampuan likuiditas jangka pendek perusahaan dengan melihat aktiva lancar perusahaan relatif terhadap utang lancarnya (utang dalam hal ini merupakan kewajiban perusahaan). 
Current ratio menunjukkan sejauhmana aktiva lancar menutupi kewajiban-kewajiban lancar. Semakin besar perbandingan aktiva lancar dan kewajiban lancar semakin tinggi kemampuan perusahaan menutupi kewajiban jangka pendeknya. Current ratio yang rendah biasanya dianggap menunjukkan terjadinya masalah dalam likuidasi, sebaliknya current ratio yang terlalu tinggi juga kurang bagus, karena menunjukkan banyaknya dana menganggur yang pada akhirnya dapat mengurangi kemampulabaan perusahaan (Sawir, 2009:10).

\section{Ukuran Perusahaan}

Dalam penelitian ini, ukuran perusahaan yang dimaksud adalah aktiva (aset). Secara sederhana, aktiva (assets) dapat didefinisikan sebagai sumber daya yang dikuasai oleh perusahaan sebagai akibat di masa depan diharapkan akan diperoleh perusahaan (Jusuf ,2014: 7).

Ukuran perusahaan yaitu perusahaan yang berskala besar pada umumnya lebih mudah memperoleh hutang dibandingkan dari perusahaan kecil karena terkait dengan tingkat kepercayaan kreditur pada perusahaanperusahaan besar (Najmudin, $2011: 316$ ).

Semakin besar ukuran suatu perusahaan, maka kecenderungan menggunakan modal asing juga semakin besar. Hal ini disebabkan karena perusahaan besar membutuhkan dana yang besar pula untuk menunjang operasionalnya, dan salah satu alternatif pemenuhannya adalah modal asing apabila modal sendiri tidak mencukupi ( Halim, $2015: 125$ ).

\section{Leverage}

Leverage rasio merupakan rasio yang digunakan untuk mengukur sejauh mana aktiva perusahaan dibiayai dengan utang. Artinya berapa besar beban utang yang ditanggung perusahaan dibandingkan dengan aktivanya ( Kasmir, 2012 : 151).

Rasio leverage adalah mengukur seberapa besar perusahaan dibiayai dengan utang. Penggunaan utang yang terlalu tinggi akan membahayakan perusahaan karena perusahaan akan masuk dalam kategori extreme leverage (utang exstrim) yaitu perusahaan terjebak dalam tingkat utang yang tinggi dan sulit untuk melepaskan beban utang tersebut ( Fahmi, $2015: 72$ ).

Leverage timbul karena perusahaan dalam operasinya menggunakan aktiva dan sumber dana yang menimbulkan beban tetap bagi perusahaan. Penggunaan aktiva yang menimbulkan beban tetap disebut dengan operating leverage (Sudana, 2011 : 157).

\section{Profitabilitas}

Menurut Sunyoto (2013:61-62), rentabilitas atau profitabilitas adalah menunjukan kemampuan perusahaan untuk menghasilkan laba selama periode tertentu. Rentabilitas suatu perusahaan diukur dengan kesuksesan perusahaan dan kemampuan menggunakan aktivanya secara produktif, dengan demikian rentabilitas suatu perusahaan dapat diketahui dengan memperbandingkan antara laba yang diperoleh dalam periode tertentu dengan jumlah aktiva atau jumlah modal perusahaan tersebut.

Menurut Sunyoto (2013:61), rentabilitas atau profitabilitas adalah menunjukkan kemampuan perusahaan untuk menghasilkan laba selama periode tertentu.

Menurut Hery (2015:226), rasio profitabilitas merupakan rasio yang digunakan untuk mengukur kemampuan perusahaan dalam menghasilkan laba dari aktivitas normal bisnisnya.

\section{Corporate Social Responsibility}

Corporate social responsibility dapat diartikan sebagai komitmen industri untuk mempertanggung jawabkan dampak operasi dalam dimensi sosial, ekonomi, dan lingkungan serta menjaga agar dampak tersebut menyumbang manfaat kepada masyarakat dan lingkungan hidupnya (Tanudjaja, 2006 dalam Melati dan Kurnia, 2013). Oleh karena itu, perusahaan semakin menyadari bahwa kelangsungan hidup perusahaan juga tergantung dari hubungan perusahaan dengan masyarakat dan lingkungannya.

Tanggung jawab sosial perusahaan yang dianggap berkualitas apabila perusahaan tersebut senantiasa melaksanakan tanggung jawab sosial dan mengungkapkannya ke dalam sustainability reporting yang penilaiannya mencakup tiga komponen utama yaitu, ekonomi, lingkungan hidup dan sosial, yang mencakup hak asasi manusia, 
praktik ketenagakerjaan, lingkungan kerja, tanggung jawab produk, dan masyarakat (Djuitaningsih dan Marsyah, 2012).

\section{Pengembangan Hipotesis}

\section{Pengaruh Likuiditas Terhadap Profitabilitas}

Menurut Syamsuddin (2013:209), penurunan rasio aktiva lancar atas total aktiva akan mengakibatkan meningkatnya baik profitabilitas maupun risiko yang dihadapi oleh perusahaan. Peningkatan profitabilitas ini disebabkan karena lebih banyak modal yang diinvestasikan dalam aktiva tetap yang dapat memberikan profitabilitas yang lebih besar dibandingkan dengan aktiva lancar.

Menurut Horne (2014 : 262),semakin besar tingkat aset lancar semakin besar juga likuiditas perusahaan, jika hal-hal lainnya sama. Dengan likuditas yang lebih besar, risiko semakin kecil, namun profitabilitas juga semakin kecil.

Menurut Husnan (2015 : 167), semakin likuid suatu aktiva maka semakin rendah kemampuan menghasilkan laba (profitabilitas) aktiva tersebut.

Berdasarkan perbedaan hasil penelitian sebelumnya maka peneliti melakukan penelitian dengan hipotesis: H1: Likuiditas Berpengaruh Terhadap Profitabilitas

\section{Pengaruh Ukuran Perusahaan Terhadap Profitabilitas}

Ukuran perusahaan merupakan kemampuan perusahaan dalam menghadapi ketidakpastian. Perusahaan dengan ukuran besar relatif lebih stabil dan lebih mampu menghasilkan laba dibandingkan dengan perusahaan kecil dan perusahaan dengan ukuran kecil pada umumnya mempunyai tingkat efisiensi yang rendah dan leverage finansial yang lebih tinggi. Investor yang bersikap hati-hati (risk adverse) cenderung melakukan investasi saham pada perusahaan besar karena mempunyai tingkat risiko lebih kecil (Sunarto, 2009: 93).

Semakin besar ukuran dari perusahaan adalah merupakan sinyal positif, sehingga perusahaan yang semakin besar cenderung semakin mendapatkan kepercayaan dari investor yang berdampak pada peningkatan harga pasar saham dari perusahaan (Meidiyustiani, $2016: 167$ ).

Berdasarkan perbedaan hasil penelitian sebelumnya maka peneliti melakukan penelitian dengan hipotesis:

H2: $\quad$ Ukuran Perusahaan Berpengaruh Terhadap Profitabilitas

\section{Pengaruh Leverage Terhadap Profitabilitas}

Menurut Riyanto (2009:51), besarnya profitabilitas modal sendiri telah dipengaruhi oleh profitabilitas ekonomi juga diperngaruhi oleh rasio utang. Pengaruh profitabilitas ekonomi terhadap profitabilitas modal sendiri selalu positif, artinya makin besar profitabilitas ekonomi selalu mengakibatkan makin besarnya profitabilitas modal sendiri, ceteris paribus, yaitu kalau faktor - faktor lainnya tetap tidak berubah, misalnya tingkat bunga, tingkat pajak dan rasio utang modal sendiri. Pengaruh rasio utang terhadap profitabilitas modal sendiri dapat positif, dapat negatif ataupun dapat tidak mempunyai pengaruh sama sekali.

Menurut Van Horne (2012 : 169), semakin besar persentase pendanaan yang disediakan oleh ekuitas pemegang saham, semakin besar jaminan perlindungan yang didapat oleh kreditur perusahaan. Singkatnya, semakin tinggi rasio utang terhadap total aset semakin besar risiko keuangannya, semakin rendah rasio ini maka akan semakin rendah risiko keuangannya.

Menurut Syamsuddin (2013 : 122), total leverage sebenarnya merupakan kombinasi dari operating dan financial leverage. Dengan demikian, tingginya operating dan financial leverage akan memperbesar pula total leverage begitu sebaliknya, operating dan financial leverage yang rendah akan memperkecil total leverage.

Berdasarkan perbedaan hasil penelitian sebelumnya maka peneliti melakukan penelitian dengan hipotesis:

\section{H3: $\quad$ Leverage Berpengaruh Terhadap Profitabilitas}

\section{Pengaruh Likuiditas Terhadap Corporate Social Responsibility}

Kemampuan perusahaan dengan likuiditas tinggi akan berhubungan dengan pengungkapan sosial yang tinggi. Dengan likuiditas yang tinggi berarti perusahaan mempunyai kemampuan untuk membiayai dan melakukan kegiatan yang berkaitan dengan pengungkapan sosial (CSR). Sehingga perusahaan lebih mampu untuk mengungkapkan kegiatan sosial yang dilakukan dengan lebih luas. Hasil penelitian dari Widianingsih (2011) 
membuktikan bahwa likuiditas mempengaruhi luas pengungkapan sukarela (CSR). Sejalan dengan penelitian Suta dan Laksito (2012) likuiditas berpengaruh negatif secara signifikan terhadap luas pengungkapan sukarela perusahaan. Bertolak belakang dengan Adhelia (2008), Prihastuti (2008), dan Badjuri (2011) menyatakan tidak berhasil menemukan pengaruh yang signifikan antara tingkat likuiditas dengan pengungkapan sosial (CSR).

Berdasarkan perbedaan hasil penelitian sebelumnya maka peneliti melakukan penelitian dengan hipotesis:

H4: Likuiditas Berpengaruh Terhadap Corporate Social Responsibility.

\section{Pengaruh Ukuran Perusahaan Terhadap Corporate Social Responsibility}

Ukuran Perusahaan adalah salah satu variabel yang paling sering digunakan dalam beberapa literatur untuk menjelaskan luas tingkat pengungkapan yang dilakukan oleh perusahaan. Salah satu alasan yang dapat dikemukakan adalah karena semakin besar Ukuran Perusahaan, maka semakin tinggi tingkat pengungkapan karena perusahaan besar harus memenuhi public demand atas pengungkapan yang lebih luas (Prasetya, 2011).

Ukuran perusahaan memiliki pengaruh positif signifikan terhadap pengungkapan tanggung jawab sosial. (Wijaya, 2012). Berbeda dengan penelitian yang dilakukan oleh Echave dan Shyam (2010) dan Bayoud (2011) bahwa ukuran perusahaan tidak memiliki pengaruh yang signifikan terhadap pengungkapan tanggung jawab sosial perusahaan.

Berdasarkan perbedaan hasil penelitian sebelumnya maka peneliti melakukan penelitian dengan hipotesis: H5

: Ukuran Perusahaan Berpengaruh Terhadap Corporate Social Responsibility

\section{Pengaruh Leverage Terhadap Corporate Social Responsibility}

Leverage digunakan untuk menjelaskan kemampuan perusahaan dalam menggunakan aset dan sumber dana untuk memperbesar hasil pengembalian kepada pemiliknya atau investor. Apabila utang perusahaan semakin besar maka financial leverage semakin besar, oleh karena itu perusahaan dengan leverage yang tinggi, akan menyebabkan investor kurang percaya terhadap laba yang dipublikasikan oleh perusahaan karena investor beranggapan bahwa perusahaan akan lebih mengutamakan pembayaran hutang terhadap kreditur daripada pembayaran dividen (Vinola, 2016:8).

Dalam penelitiannya Politon dan Rustiyaningsih (2013) menyatakan bahwa leverage berpengaruh positif dan tidak signifikan terhadap pengungkapan tanggung jawab sosial perusahaan, berbeda dengan hasil penelitian Wardani dan Januarti (2013) dan Echave dan Shyam (2010) yang menyatakan bahwa leverage tidak berpengaruh secara signifikan terhadap pengungkapan tanggung jawab sosial perusahaan.

Berdasarkan perbedaan hasil penelitian sebelumnya maka peneliti melakukan penelitian dengan hipotesis:

\section{$\mathrm{H}_{6}: \quad$ Leverage Berpengaruh Terhadap Corporate Social Responsibility}

\section{Pengaruh Profitabilitas Terhadap Corporate Social Responsibility}

Tingkat profitabilitas perusahaan tidak mempengaruhi luas pengungkapan informasi sosialnya. Perusahaan dengan tingkat laba yang tinggi belum tentu mampu mengalokasikan kelebihan dananya untuk hal-hal lain, salah satunya untuk melakukan kegiatan sosial beserta pengungkapannya (Rahajeng, 2010 dalam Ihsan, 2014 :6).

Profitabilitas Perusahaan memiliki pengaruh yang signifikan terhadap luas pengungkapan tanggung jawab sosial. (Wardani dan Januarti, 2013).

Berdasarkan perbedaan hasil penelitian sebelumnya maka peneliti melakukan penelitian dengan hipotesis:

\section{$\mathrm{H}_{7}$ : $\quad$ Profitabilitas Berpengaruh Terhadap Corporate Social Responsibility}

\section{Rancangan Penelitian}

\section{METODOLOGI PENELITIAN}

Dalam penelitian ini alat statistik yang digunakan antara lain statistik deskriptif korelasional. Metode deskriptif korelasional dipandang sesuai dengan penelitian ini karena bertujuan untuk memperoleh gambaran tentang variabel yang diteliti dan bersifat korelasi karena penelitian ini bertujuan untuk menemukan ada tidaknya hubungan dan apabila ada, seberapa eratnya hubungan tersebut, serta berarti atau tidaknya hubungan tersebut. 


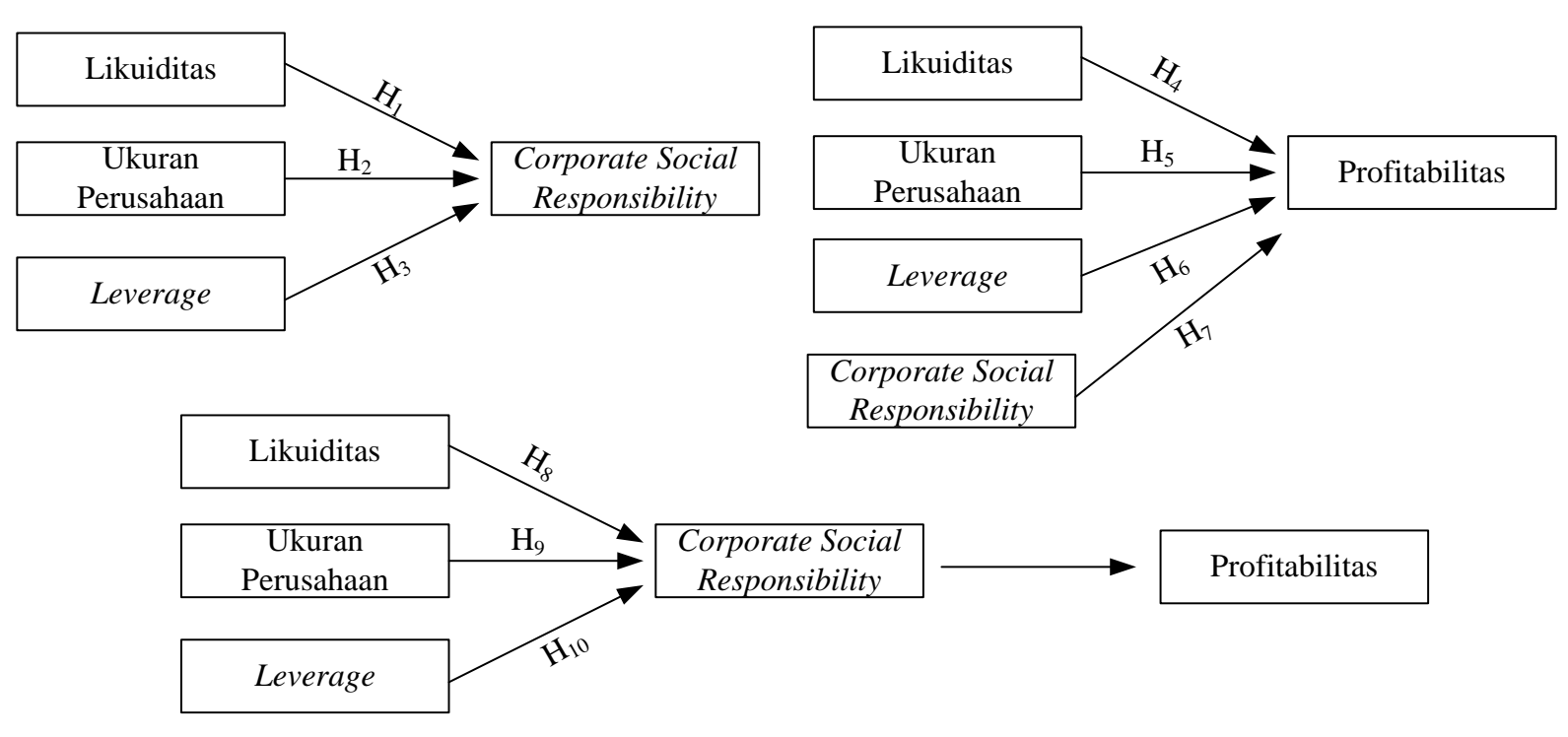

Gambar 1. Konsep Penelitian

Sumber : Kajian teori yang dikembangkan, 2017

\section{Pengukuran Variabel}

\section{a. Profitabilitas}

Indikator profitabilitas dalam penelitian ini menggunakan ROA (Return on Asset), Menurut Hery (2015:228), rumus yang digunakan untuk mencari ROA (Return on Asset) sebagai berikut :

Return on Asset $=\frac{\text { Laba Bersih }}{\text { Total Aset }}$

\section{b. Corporate Social Responsibility}

Instrumen pengungkapan CSR diukur dengan proksi CSRDI (corporate social responsibility disclosure index) berdasarkan GRI (global reporting initiatives). Indikator GRI terdiri dari 3 fokus pengungkapan, yaitu ekonomi, lingkungan, dan sosial sebagai dasar sustainability reporting.

Instrumen pengukuran CSR yang digunakan dalam penelitian ini mengacu pada instrumen yang digunakan oleh Silalahi (2014), yang mengelompokkan informasi CSR ke dalam 7 kategori, yaitu:

1. Lingkungan

2. Energi

3. Kesehatan dan Keselamatan Tenaga Kerja

4. Lain-lain Tenaga Kerja

5. Produk

6. Keterlibatan Masyarakat, dan

7. Umum

Total item CSR maksimal adalah 78. Variabel ini memiliki skala rasio dan diukur dengan menggunakan checklist CSR items. Setiap item CSR dalam instrumen penelitian diberi nilai 1 jika diungkapkan, dan nilai 0 jika tidak diungkapkan. Variabel ini menggunakan skala nominal dengan menggunakan pengukuran variabel dummy. Rumus perhitungan CSR mengacu pada penelitian adalah Sayekti dan Wondabio (2007); Silalahi (2014) sebagai berikut :

$\mathrm{CSRI}=\frac{\sum \mathrm{n}}{78}$

Keterangan :

CSRI = Corporate Social Responsibility Index

$\mathrm{n} \quad=$ Jumlah item pengungkapan yang dipenuhi 
$78=$ Total seluruh item GRI

c. Likuiditas

Current ratio digunakan untuk mengukur kemampuan korporasi dalam memenuhi kewajiban jangka pendek, dengan asumsi bahwa semua aktiva lancar dikonversikan ke dalam kas, indikator yang digunakan untuk menghitung rasio lancar adalah dengan rumus (Tampubolon,2013:41) :

Current Ratio $=\frac{\text { Aktiva Lancar }(\text { current assets })}{\text { Pasiva Lancar }(\text { current liabilitie s })}$

\section{d. Ukuran Perusahaan}

Indikator ukuran perusahaan dalam penelitian ini menggunakan firm size didefinisikan sebagai logaritma dari net sales (Mulyawan, $2015: 247$ ).

\section{e. Leverage}

Indikator dalam penelitian ini menggunakan debt ratio. debt ratio merupakan rasio utang yang digunakan untuk mengukur perbandingan antara total utang dengan total aktiva (Kasmir, $2012: 156)$.

Debt ratio $(D R)=\frac{\text { Total debt }}{\text { Total aset }}$

\section{Populasi dan Sampel}

Populasi yang digunakan dalam penelitian ini adalah perusahaan consumer goods yang terdaftar di Bursa Efek Indonesia tahun 2011-2015. Dari populasi tersebut dapat ditarik sampel dengan metode purposive sampling yaitu teknik pengambilan sampel dengan kriteria-kriteria tertentu sesuai dengan tujuan dari penelitian. Kriteria pemilihan sampel yang ditentukan sebagai berikut :

1. Perusahaan consumer goods yang terdaftar di Bursa Efek Indonesia (BEI) tahun 2011-2015.

2. Perusahaan consumer goods yang datanya ditemukan pada BEI periode 2011-2015.

3. Perusahaan consumer goods yang di dalam laporan keuangan terdapat hasil laba bersih periode 2011-2015.

4. Perusahaan consumer goods yang mempublikasikan secara lengkap laporan keuangan tahunan yang teah diaudit periode 2011-2015.

Tabel 1. Sampel

\begin{tabular}{|l|l|}
\hline Kriteria & Sampel \\
\hline $\begin{array}{l}\text { Perusahaan consumer goods yang terdaftar di Bursa Efek Indonesia (BEI) tahun 2011- } \\
2015 .\end{array}$ & 39 \\
\hline $\begin{array}{l}\text { Perusahaan sub-sektor consumer goods yang datanya tidak ditemukan pada BEI periode } \\
\text { 2011-2015. }\end{array}$ & $(8)$ \\
\hline $\begin{array}{l}\text { Perusahaan yang terdaftar dalam sub-sektor consumer goods di BEI periode 2011-2015 } \\
\text { yang memiliki rugi bersih. }\end{array}$ & $(7)$ \\
\hline $\begin{array}{l}\text { Perusahaan sub-sektor consumer goods yang tidak mempublikasikan secara lengkap } \\
\text { laporan keuangan tahunan yang teah diaudit periode 2011-2015. }\end{array}$ & $(10)$ \\
\hline Jumlah perusahaan yang terpilih menjadi sampel penelitian & $\mathbf{1 4}$ \\
\hline
\end{tabular}




\section{HASIL PENELITIAN DAN PEMBAHASAN}

\section{Hasil Penelitian}

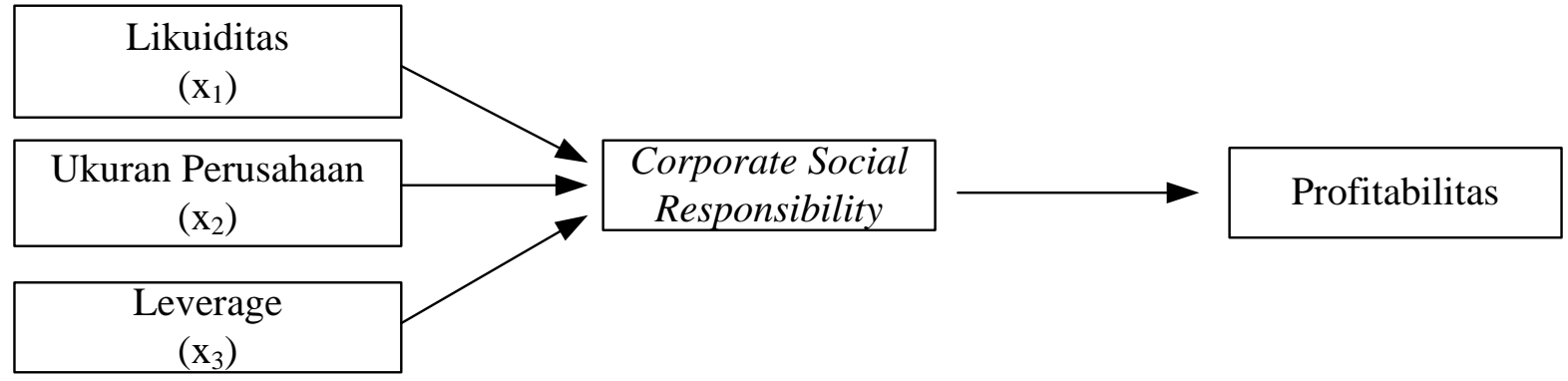

Penelitian ini menggunakan dua tahapan yaitu analisis substruktural 1 dan analisis substruktural 2.

Menentukan besarnya koefisien determinasi ( Rsquare/ $\mathbf{R}^{\mathbf{2}}$ )

Analisis substruktural 1

Tabel 2 Koefisien Determinasi

Model Summary

\begin{tabular}{|l|l|r|r|r|r|}
\hline Model & $\mathrm{R}$ & $\mathrm{R}$ Square & $\begin{array}{c}\text { Adjusted R } \\
\text { Square }\end{array}$ & $\begin{array}{c}\text { Std. Error of } \\
\text { the Estimate }\end{array}$ & $\begin{array}{c}\text { Durbin- } \\
\text { Watson }\end{array}$ \\
\hline 1 & $.612^{\mathrm{a}}$ & .375 & .347 & .05928 & 1.030 \\
\hline
\end{tabular}

a. Predictors: (Constant), In_Debt_Ratio, In_Ukuran_Perusahaan,

In_Current_Ratio

b. Dependent Variable: In_CSR

Sumber : data diolah,2017

Analisis substruktural 2

Tabel 3 Koefisien Determinasi

Model Summary

\begin{tabular}{|l|l|l|r|r|r|}
\hline Model & $\mathrm{R}$ & R Square & $\begin{array}{c}\text { Adjusted R } \\
\text { Square }\end{array}$ & $\begin{array}{c}\text { Std. Error of } \\
\text { the Estimate }\end{array}$ & $\begin{array}{c}\text { Durbin- } \\
\text { Watson }\end{array}$ \\
\hline 1 & $.279^{a}$ & .078 & .021 & .71610 & 2.194 \\
\hline
\end{tabular}

a. Predictors: (Constant), In_CSR, In_Debt_Ratio, In_Current_Ratio,

In_Ukuran_Perusahaan

b. Dependent Variable: In_ROA

Sumber : data diolah, 2017

Pengujian Hipotesis

Analisis substruktural 1

Uji Simultan (Uji F)

Tabel 4 Hasil Uji Simultan

\begin{tabular}{|c|c|c|c|c|c|c|}
\hline \multicolumn{7}{|c|}{ ANOVA ${ }^{b}$} \\
\hline & & $\begin{array}{c}\text { Sum of } \\
\text { Squares }\end{array}$ & df & Mean Square & $\mathrm{F}$ & Sig. \\
\hline \multirow[t]{3}{*}{1} & Regression & .148 & 4 & .037 & 10.742 & $.000^{a}$ \\
\hline & Residual & .223 & 65 & .003 & & \\
\hline & Total & .371 & 69 & & & \\
\hline
\end{tabular}

Sumber : data diolah, 2017 
Uji Parsial (Uji t)

Tabel 5 Hasil Uji Parsial

Coefficients ${ }^{a}$

\begin{tabular}{|c|c|c|c|c|c|c|c|c|}
\hline \multirow[b]{2}{*}{ Mod } & & \multicolumn{2}{|c|}{ Unstandardized Coefficients } & \multirow{2}{*}{$\begin{array}{c}\text { Standardized } \\
\text { Coefficients } \\
\text { Beta }\end{array}$} & \multirow[b]{2}{*}{$\mathrm{t}$} & \multirow[b]{2}{*}{ Sig. } & \multicolumn{2}{|c|}{ Collinearity Statistics } \\
\hline & & $B$ & Std. Error & & & & Tolerance & VIF \\
\hline \multirow[t]{5}{*}{1} & (Constant) & -2.400 & .395 & & -6.077 & .000 & & \\
\hline & In_Current_Ratio & -.035 & .012 & -.298 & -2.876 & .005 & .861 & 1.161 \\
\hline & In_Ukuran_Perusahaan & .632 & .117 & .537 & 5.389 & .000 & .931 & 1.074 \\
\hline & In_Debt_Ratio & .010 & .012 & .086 & .802 & .425 & .804 & 1.244 \\
\hline & In_ROA & -.016 & .010 & -.155 & -1.575 & .120 & .957 & 1.045 \\
\hline
\end{tabular}

a. Dependent Variable: In_CSR

Sumber : data diolah, 2017

Analisis substruktural 2

Uji Simultan (Uji F)

Tabel 6 Hasil Uji Simultan

\begin{tabular}{|c|c|c|c|c|c|c|}
\hline \multicolumn{7}{|c|}{ ANOVA } \\
\hline \multicolumn{2}{|c|}{ Model } & $\begin{array}{l}\text { Sum of } \\
\text { Squares }\end{array}$ & df & Mean Square & $\mathrm{F}$ & Sig. \\
\hline \multirow[t]{3}{*}{1} & Regression & 2.812 & 4 & .703 & 1.371 & $.254^{a}$ \\
\hline & Residual & 33.332 & 65 & .513 & & \\
\hline & Total & 36.144 & 69 & & & \\
\hline
\end{tabular}

a. Predictors: (Constant), In_CSR,In_Debt_Ratio, In_Current_Ratio,

In_Ukuran_Perusahaan

b. Dependēnt Variable: In_ROA

Sumber : data diolah, 2017

Uji Parsial (Uji t)

Tabel 7 Hasil Uji Parsial

Coefficients $^{a}$

\begin{tabular}{|c|c|c|c|c|c|c|c|c|}
\hline \multirow[b]{2}{*}{ Mod } & & \multicolumn{2}{|c|}{ Unstandardized Coefficients } & \multirow{2}{*}{$\begin{array}{c}\begin{array}{c}\text { Standardized } \\
\text { Coefficients }\end{array} \\
\text { Beta }\end{array}$} & \multirow[b]{2}{*}{$\mathrm{t}$} & \multirow[b]{2}{*}{ Sig. } & \multicolumn{2}{|c|}{ Collinearity Statistics } \\
\hline & & $B$ & Std. Error & & & & Tolerance & VIF \\
\hline \multirow[t]{5}{*}{1} & (Constant) & -9.949 & 5.914 & & -1.682 & .097 & & \\
\hline & In_Current_Ratio & .027 & .156 & .024 & .175 & .862 & .764 & 1.308 \\
\hline & In_Ukuran_Perusahaan & 2.106 & 1.704 & .181 & 1.236 & .221 & .659 & 1.518 \\
\hline & In_Debt_Ratio & -.118 & .150 & -.104 & -.786 & .434 & .804 & 1.244 \\
\hline & In_CSR & -2.342 & 1.487 & -.237 & -1.575 & .120 & .625 & 1.600 \\
\hline
\end{tabular}

a. Dependent Variable: In ROA

Sumber : data diolah, 2017

\section{Pembahasan}

Dari hasil pengujian substruktural $1 \mathrm{di}$ atas diketahui bahwa secara simultan likuiditas, ukuran perusahaan, leverage, mempunyai pengaruh yang signifikan terhadap corporate social responsibility. Hal ini didasarkan pada perbandingan Fhitung dengan Ftabel dan signifikansi hitung berada di angka 0,05. Berdasarkan hasil pengujian statistik Uji Simultan (Uji F) Fhitung diperoleh angka 10,742 > dari Ftabel 2,74 dan sig. hitung 0,000 $<0,05(\alpha$ : $5 \%)$. Angka R Square yaitu 0,375 merupakan angka pengkuadratan dari koefisien korelasi atau $(0.612) 2=0,375$. $R$ 
Square biasa disebut dengan koefisien determinasi, angka tersebut berarti 37,5\% pengungkapan tanggung jawab sosial dapat dijelaskan oleh variabel likuiditas, ukuran perusahaan, leverage. Sedangkan sisanya $(100 \%-37,5 \%=$ $62,5 \%)$ disebabkan oleh faktor-faktor lain.

Hasil uji statistik variabel likuiditas $\left(\mathrm{X}_{1}\right) \mathrm{t}$ hitung dan sig. hitung diperoleh angka $-2.876<\mathrm{t}_{\text {tabel }} 1,995$ dan sig. hitung $0,000<0,05(\alpha: 5 \%)$ dengan demikian likuiditas $\left(\mathrm{X}_{1}\right)$ berpengaruh signifikan terhadap corporate social responsibility $\left(\mathrm{Y}_{1}\right)$. Hasil penelitian ini Sejalan dengan penelitian Suta dan Laksito (2012) likuiditas berpengaruh negatif secara signifikan terhadap luas pengungkapan sukarela perusahaan. Namun bertolak belakang dengan Adhelia (2008), Prihastuti (2008), dan Badjuri (2011) menyatakan tidak berhasil menemukan pengaruh yang signifikan antara tingkat likuiditas dengan pengungkapan sosial (CSR).

Hasil uji statistik variabel ukuran perusahaan (X2) t hitung dan sig. hitung diperoleh angka 5,389 > t tabel 1,995 dan sig. hitung $0,005<0,05(\alpha: 5 \%)$ dengan demikian ukuran perusahaan (X2) berpengaruh signifikan terhadap corporate social responsibility (Y1). Hasil penelitian ini sejalan dengan penelitian yang dilakukan oleh Wijaya (2012), ukuran perusahaan memiliki pengaruh positif signifikan terhadap pengungkapan tanggung jawab sosial. namun bertolak belakang dengan penelitian yang dilakukan oleh Echave dan Shyam (2010) dan Bayoud (2011) bahwa ukuran perusahaan tidak memiliki pengaruh yang signifikan terhadap pengungkapan tanggung jawab sosial perusahaan.

Hasil uji statistik variabel leverage (X3) t hitung dan sig. hitung diperoleh angka 0,802< ttabel 1,995 dan sig. hitung 0,425>0,05 ( $\alpha$ : 5\%) dengan demikian leverage (X3) tidak berpengaruh signifikan terhadap corporate social responsibility (Y1). Hasil penelitian ini sejalan dengan hasil penelitian yang dilakukan Wardani dan Januarti (2013) dan Echave dan Shyam (2010) yang menyatakan bahwa leverage tidak berpengaruh secara signifikan terhadap pengungkapan tanggung jawab sosial perusahaan. Namun berbeda dengan penelitian yang dilakukan oleh Politon dan Rustiyaningsih (2013) menyatakan bahwa leverage berpengaruh positif dan tidak signifikan terhadap pengungkapan tanggung jawab sosial perusahaan.

Pengujian substruktural 2 di atas diketahui bahwa secara simultan likuiditas, ukuran perusahaan, leverage dan corporate social responsibility tidak mempunyai pengaruh yang signifikan terhadap profitabilitas. Hal ini didasarkan pada perbandingan Fhitung dengan Ftabel dan signifikansi hitung berada di angka 0,05. Berdasarkan hasil pengujian statistik Uji Simultan (Uji F) Fhitung diperoleh angka 1,371 < dari Ftabel 2,74 dan sig. hitung 0,254 $>0,05(\alpha: 5 \%)$. Angka R Square yaitu 0,078 merupakan angka pengkuadratan dari koefisien korelasi atau $(0,279) 2$ $=0,078$. R Square biasa disebut dengan koefisien determinasi, angka tersebut berarti 7,8\% profitabilitas dapat dijelaskan oleh variabel likuiditas, ukuran perusahaan, leverage dan corporate social responsibility. Sedangkan sisanya $(100 \%-7,8 \%=92,2 \%)$ disebabkan oleh faktor-faktor lain.

Hasil uji statistik variabel likuiditas $\left(\mathrm{X}_{1}\right) \mathrm{t}_{\text {hitung }}$ dan sig. hitung diperoleh angka $0,175<\mathrm{t}_{\text {tabel }} 1,995$ dan sig. hitung 0,862 >0,05 $(\alpha: 5 \%)$ dengan demikian likuiditas $\left(\mathrm{X}_{1}\right)$ tidak berpengaruh signifikan terhadap profitabilitas $\left(\mathrm{Y}_{2}\right)$. Hasil penelitian ini sejalan dengan teori Horne (2014 : 262), semakin besar tingkat aset lancar semakin besar juga likuiditas perusahaan, jika hal-hal lainnya sama. Dengan likuditas yang lebih besar, risiko semakin kecil, namun profitabilitas juga semakin kecil.

Hasil uji statistik variabel ukuran perusahaan $\left(\mathrm{X}_{2}\right) \mathrm{t}$ hitung dan sig. hitung diperoleh angka $1,236<\mathrm{t}$ tabel 1,995 dan sig. hitung $0,221>0,05\left(\alpha\right.$ : 5\%) dengan demikian ukuran perusahaan $\left(\mathrm{X}_{2}\right)$ berpengaruh signifikan terhadap profitabilitas $\left(\mathrm{Y}_{2}\right)$. Hasil penelitian ini sejalan dengan penelitian yang dilakukan oleh Meidiyustiani (2016), Semakin besar ukuran dari perusahaan adalah merupakan sinyal positif, sehingga perusahaan yang semakin besar cenderung semakin mendapatkan kepercayaan dari investor yang berdampak pada peningkatan harga pasar saham dari perusahaan.

Hasil uji statistik variabel leverage (X3) t hitung dan sig. hitung diperoleh angka $-0,786<$ ttabel 1,995 dan sig. hitung $0,443>0,05(\alpha: 5 \%)$ dengan demikian leverage (X3) tidak berpengaruh signifikan terhadap profitabilitas(Y2). Hasil penelitian ini sejalan dengan teori Syamsuddin (2013 : 122), total leverage sebenarnya merupakan kombinasi dari operating dan financial leverage. Dengan demikian, tingginya operating dan financial leverage akan memperbesar pula total leverage begitu sebaliknya, operating dan financial leverage yang rendah akan memperkecil total leverage.

Hasil uji statistik variabel corporate social responsibility (Y1) t hitung dan sig. hitung diperoleh angka $-1,575$ $<\mathrm{t}$ tabel 1,995 dan sig. hitung 0,120 >0,05 ( $\alpha$ : 5\%) dengan demikian corporate social responsibility tidak berpengaruh signifikan terhadap profitabilitas (Y2). Hasil penelitian ini sejalan dengan hasil penelitian tidak sejalan 
yang dilakukan Wardani dan Januarti (2013), profitabilitas perusahaan memiliki pengaruh yang signifikan terhadap luas pengungkapan tanggung jawab sosial. Namun sejalan dengan Rahajeng (2010), Tingkat profitabilitas perusahaan tidak mempengaruhi luas pengungkapan informasi sosialnya. Perusahaan dengan tingkat laba yang tinggi belum tentu mampu mengalokasikan kelebihan dananya untuk hal-hal lain, salah satunya untuk melakukan kegiatan sosial beserta pengungkapannya.

Koefisien pengaruh langsung likuiditas (X1) terhadap corporate social responsibility $(\mathrm{Y} 1)$ adalah $\beta 1=-$ 0,298 . Koefisien pengaruh langsung corporate social responsibility $(\mathrm{Y} 1)$ terhadap profitabilitas (Y2) adalah $\beta 9=-$ 0,237 . Koefisien pengaruh langsung likuiditas (X1) terhadap profitabilitas (Y2) adalah $\beta 5=0,024$. Koefisien pengaruh tidak langsung likuiditas (X1) terhadap profitabilitas (Y2) melalui corporate social responsibility (Y1) adalah $\beta 10=\beta 1 \times \beta 9=-0,298 \times(-0,237)=0,0706$. Dengan demikian koefisien pengaruh secara langsung $(\beta 10=$ $0,0706)<$ koefisien pengaruh langsung $(\beta 5=0,024)$, artinya likuiditas $(\mathrm{X} 1)$ tidak berpengaruh signifikan terhadap profitabilitas (Y2) melalui corporate social responsibility (Y1).

Koefisien pengaruh langsung ukuran perusahaan (X2) terhadap corporate social responsibility (Y1) adalah $\beta 2=0,537$. Koefisien pengaruh langsung corporate social responsibility (Y1) terhadap profitabilitas (Y2) adalah $\beta 9$ $=-0,237$. Koefisien pengaruh langsung ukuran perusahaan (X2) terhadap corporate social responsibility (Y2) adalah $\beta 5=0,181$. Koefisien pengaruh tidak langsung ukuran perusahaan (X2) terhadap profitabilitas (Y2) melalui corporate social responsibility (Y1) adalah $\beta 11=\beta 2 \times \beta 9=0,537 \times-0,237=-0,127$. Dengan demikian koefisien pengaruh tidak langsung $(\beta 11=-0,127)>$ koefisien pengaruh langsung $(\beta 6=0,181)$, artinya ukuran perusahaan (X2) berpengaruh signifikan terhadap profitabilitas (Y2) melalui corporate social responsibility (Y1).

Koefisien pengaruh langsung leverage (X3) terhadap corporate social responsibility (Y1) adalah $\beta 3=0,086$. Koefisien pengaruh langsung corporate social responsibility (Y1) terhadap profitabilitas (Y2) adalah $\beta 9=-0,237$. Koefisien pengaruh langsung leverage (X3) terhadap profitabilitas (Y2) adalah $\beta 7=-0,104$. Koefisien pengaruh tidak langsung leverage (X3) terhadap profitabilitas (Y2) melalui corporate social responsibility (Y1) adalah $\beta 12=$ $\beta 3 \times \beta 9=0,086 \times-0,237=0,0203$. Dengan demikian koefisien pengaruh tidak langsung $(\beta 12=0,0203)>$ koefisien pengaruh langsung $(\beta 7=-0,104)$, artinya leverage $(\mathrm{X} 3)$ berpengaruh signifikan terhadap profitabilitas (Y2) melalui corporate social responsibility (Y1).

\section{Kesimpulan}

\section{PENUTUP}

1. Likuiditas, ukuran perusahaan, leverage, mempunyai pengaruh yang signifikan terhadap corporate social responsibility pada perusahaan consumer goods yang terdaftar di Bursa Efek Indonesia periode 2011 - 2015.

2. Likuiditas $\left(\mathrm{X}_{1}\right)$ berpengaruh signifikan terhadap corporate social responsibility $\left(\mathrm{Y}_{1}\right)$ dengan demikian $\mathrm{H}_{1}$ diterima.

3. Ukuran perusahaan $\left(\mathrm{X}_{2}\right)$ berpengaruh signifikan terhadap corporate social responsibility $\left(\mathrm{Y}_{1}\right)$ dengan demikian $\mathrm{H}_{2}$ diterima.

4. Leverage $\left(\mathrm{X}_{3}\right)$ tidak berpengaruh signifikan terhadap corporate social responsibility $\left(\mathrm{Y}_{1}\right)$ dengan demikian $\mathrm{H}_{3}$ ditolak.

5. Likuiditas $\left(\mathrm{X}_{1}\right)$ tidak berpengaruh signifikan terhadap profitabilitas $\left(\mathrm{Y}_{2}\right)$ dengan demikian $\mathrm{H}_{4}$ ditolak.

6. Ukuran Perusahaan $\left(\mathrm{X}_{2}\right)$ berpengaruh signifikan terhadap profitabilitas $\left(\mathrm{Y}_{2}\right)$ dengan demikian $\mathrm{H}_{5}$ diterima.

7. Leverage $\left(\mathrm{X}_{3}\right)$ tidak berpengaruh signifikan terhadap profitabilitas $\left(\mathrm{Y}_{2}\right)$ dengan demikian $\mathrm{H}_{6}$ ditolak.

8. Corporate social responsibility $\left(\mathrm{Y}_{1}\right)$ tidak berpengaruh signifikan terhadap profitabilitas $\left(\mathrm{Y}_{2}\right)$ dengan demikian $\mathrm{H}_{7}$ ditolak.

9. Likuiditas (X1) tidak berpengaruh signifikan terhadap profitabilitas $\left(\mathrm{Y}_{2}\right)$ melalui corporate social responsibility $\left(\mathrm{Y}_{1}\right)$ dengan demikian $\mathrm{H}_{8}$ ditolak.

10. Ukuran perusahaan (X2) berpengaruh signifikan terhadap profitabilitas (Y2) melalui corporate social responsibility (Y1) dengan demikian $\mathrm{H}_{9}$ diterima.

11. Leverage (X3) berpengaruh signifikan terhadap profitabilitas (Y2) melalui corporate social responsibility (Y1) dengan demikian $\mathrm{H}_{10}$ diterima. 


\section{Saran}

1. Bagi perusahaan, perlu memperhatikan likuiditas, ukuran perusahaan, leverage dan corporate social responsibility sebagai indikator yang secara bersama-sama atau simultan dapat mempengaruhi profitabilitas perusahaan consumer goods yang terdaftar di BEI. Perusahaan juga hendaknya lebih peduli dalam hal pengungkapan corporate social responsibility bukan hanya sebagai ketentuan perundang-undangan tapi juga sebagai salah satu kewajiban perusahaan yang harus dilaksanakan dan disampaikan kepada para stakeholder meskipun untuk saat ini corporate social responsibility masih belum memberikan pengaruh positif yang signifikan bagi perusahaan. Para investor masih lebih menilai likuiditas, ukuran perusahaan, dan leverage dalam pengambilan keputusan investasi.

2. Bagi investor, pengambilan keputusan yang baik dan tepat dalam hal berinvestasi untuk suatu perusahaan perlu analisis yang baik dalam hal analisis fundamental. Para investor juga hendaknya dapat mendorong perusahaan untuk melakukan corporate social responsibility-nya, untuk mendapatkan gambaran yang jelas mengenai kondisi perusahaan.

\section{DAFTAR PUSTAKA}

Adhelia, Hexa. 2008. Analisis Faktor-Faktor yang Mempengaruhi Kelengkapan Pengungkapan Sosial dalam Laporan Tahunan Perusahaan (Studi pada Perusahaan High Profile yang Terdaftar di BEI). Fakultas Ekonomi Universitas Brawijaya. Malang.

Badjuri, Achmad. 2011. Faktor-faktor Fundamental, Mekanisme Corporate Governance, Pengungkapan Corporate Social Responsibility (CSR) Perusahaan Manufaktur dan Sumber Daya Alam di Indonesia. Dinamika Keuangan dan Perbankan. Universitas Stikubank.

Djuitaningsih, Tita dan Wahdatul A Marsyah. 2012. Pengaruh Manajemen Laba Dan Mekanisme Corporate Governance Terhadap Corporate Social Responsibility Disclosure. Media Riset Akuntansi, Vol. 2 No.2 Agustus. Universitas Bakrie.

Echave, Jon dan Shyam S. Bhati. 2010. Determinants of Social and Environmental Disclosure by Spanish Companies. GSMI Third Annual International Business Conference. Michigan, USA

Erdanu, Yudho. 2010. Pengaruh Jenis Industri terhadap Luas Pengungkapan Tanggungjawab Sosial (CSR Disclosure) pada Laporan Tahunan Perusahaan: Studi Empiris pada Perusahaan Publik yang Tercatat di Bursa Efek Indonesia Tahun 2009. Semarang: Fakultas Ekonomi Universitas Diponegoro.

Fahmi, Irham. 2013. Pengantar Manajemen Keuangan. Cetakan Kedua. Bandung : Alfabeta.

Herawaty, Vinola dan Ganiz Yudhadhita Wijaya. 2016. Pengaruh Pengungkapan Corporate Social Responsibility, Profitabilitas, dan Leverage Terhadap Keinformatifan laba dengan kinerja lingkungan sebagai Variabel Moderasi. Simposium Nasional Akuntansi XIX, Lampung.

Hanafi, Mamduh M. dan Abdul Halim. 2014. Analisis Laporan Keuangan. Yogyakarta : Penerbit UPP STIM YKPN.

Halim, Abdul. 2015. Manajemen Keuangan Bisnis : Konsep dan Aplikasinya. Edisi Pertama. Jakarta : Mitra Wacana Media.

Hery. 2015. Analisis Laporan Keuangan. Jakarta : Penerbit CAPS.

Januarti dan Nurul K. Wardani.2013. Pengaruh Karakteristik Perusahaan Terhadap Pengungkapan Corporate Social Responsibility (CSR) (Studi Empiris Pada Perusahaan manufaktur yang Terdaftar di Bursa Efek Indonesia tahun (2009 - 2011). Diponegoro Journal Of Accounting Vol 2, No. 2. Universitas Diponegoro, Semarang.

Ihsan, Alifi Khoirul. 2014. Pengaruh Ukuran Perusahaan, Leverage, Likuiditas, dan Profitabilitas Terhadap Luas Pengungkapan Sosial Dalam Laporan Tahunan Perusahaan (Studi Empiris pada Perusahaan Manufaktur yang Terdaftar di BEI). Artikel Ilmiah Mahasiswa.

Kamaludin dan Indriani, Rini.2012.Manajemen Keuangan Konsep Dasar dan Penerapannya. Edisi Revisi. Bandung : Penerbit CV. Mandar Maju.

Kasmir. 2013. Analisis Laporan Keuangan. Edisi Pertama. Cetakan keenam. Jakarta : PT.Raja Grafindo Persada. Jusuf, Jopie. 2014. Analisis Kredit. Jakarta : PT.Gramedia Pustaka Utama.

Murhadi, Werner. 2013. Analisis Laporan Keuangan Proyeksi dan Valuasi Saham. Jakarta : Penerbit Salemba Empat. 
Melati, Rosa Aprilia dan Kurnia. 2013. Pengaruh Pengungkapan Informasi CSR dan Profitabilitas Terhadap Earning Response Coefficient (ERC). Jurnal Ilmu \& Riset Akutansi Vol. 2 No. 12.

Mulyawan, Setia. 2015. Manajemen Keuangan. Bandung: Pustaka Setia.

Munadhiroh, Attin dan Nurchayati. 2015. Pengaruh Arus Kas Operasi dan Likuiditas Terhadap Profitabilitas (Studi Empiris Pada Perusahaan Property dan Real Estate Yang Terdaftar di BEI). Jurnal Ilmiah UNTAG Semarang, vol 4, no 3.

Meidiyustiani, Rinny. 2016. Pengaruh Modal Kerja, Ukuran Perusahaan, Pertumbuhan Penjualan dan Likuiditas Terhadap Profitabilitas pada Perusahaan Manufaktur Sektor Industri Barang Konsumsi yang Terdaftar di Bursa Efek Indonesia (BEI) Periode Tahun 2010 - 2014. Jurnal Akuntansi dan Keuangan. Vol. 5. No.2. Oktober.

Najmudin. 2011. Manajemen Keuangan dan Aktualisasi Syar'iyyah Modern. Yogyakarta : Penerbit Andi.

Prihastuti, Theresia. 2008. Analisis Pengaruh Ukuran Perusahaan, Likuiditas, Leverage, dan Profitabilitas Terhadap Voluntary Disclosure (Study Empiris pada Perusahaan Manufaktur yang Tercatat di Bursa Efek Jakarta Tahun 2003-2006, Rangkuman Skripsi Sekolah Tinggi Ilmu Ekonomi Perbanas. Surabaya.

Prasetya, Denny Indra. 2011. Analisis Pengaruh Ukuran Perusahaan, Likuiditas, Leverage, dan Profitabilitas Terhadap Mandatory Disclosure. Fakultas Ekonomi Universitas Diponegoro.

Politon, Sontry O. dan Sri Rustiyaningsih. 2013. Karakteristik Perusahaan dan Pengungkapan Tanggung Jawab Sosial pada Perusahaan Manufaktur Go Publik. Jurnal Riset Manajemen dan Akuntansi Vol. 1 No. 1. Universitas Katolik Widya Mandala Madiun.

Riyanto, Bambang. 2015. Dasar-Dasar Pembelanjaan Perusahaan. Yogyakarta : BPFE.

Rofika. 2015. Faktor-Faktor yang Mempengaruhi Earnings Response Coefficient (ERC) Perusahaan Manufaktur yang Terdaftar di Bursa Efek Indonesia 2012. Jurnal Akuntansi, Vol. 3, No. 2, April: 174-183.

Sembiring, Eddy Rismanda. 2005. Karakteristik Perusahaan dan Pengungkapan Tanggung Jawab Sosial : Study Empiris pada Perusahaan yang Tercatat di Bursa Efek Jakarta. Jurnal, Universitas Katolik St.Thomas Sumatera Utara, Medan.

Sawir, Agnes. 2009. Analisis Kinerja Keuangan Teori dan Perencanaan Keuangan Perusahaan. Jakarta : PT.Gramedia Pustaka Umum.

Koencoro, Bambang dan Marlien. 2009. Pengaruh leverage, ukuran dan pertumbuhan Perusahaan Terhadap Profitabilitas. TEMA. ISSN : 1693 - 9727. Vol.6. No.1. Maret. Hal $86-103$.

Sudana, I Made. 2011. Manajemen Keuangan Perusahaan Teori \& Praktek. Jakarta: Penerbit Erlangga.

Suta, A. Y. dan H. Laksito. 2012. Analisis Faktor-faktor yang Mempengaruhi Luas Pengungkapan Informasi Sukarela Laporan Tahunan (Studi Empiris pada Perusahaan Manufaktur yang terdaftar di Bursa Efek Indonesia Tahun 2008-2010), Jurnal Akuntansi Diponegoro. Volume 1, Nomor 1.

Sunyoto, Danang. 2013. Analisis Laporan Keuangan untuk Bisnis (Teori dan Kasus). Cetakan 1. Yogyakarta : Penerbit CAPS.

Syamsuddin, Lukman. 2013. Manajemen Keuangan Perusahaan : Konsep Aplikasi dalam Perencanaan, Pengawasan, dan Pengambilan Keputusan. Cetakan kedua belas. Jakarta : PT.Raja Grafindo Persada.

Tampubolon, Manahan. 2013. Manajemen Keuangan. Jakarta : Mitra Wacana Media.

Utari, Dewi, Ari Purwanti dan Darsono Prawironegoro. 2014. Manajemen Keuangan. Jakarta : Penerbit Mitra Wacana Media.

Van Horne, James C dan John M.Wachowicz,Jr.2014. Prinsip-Prinsip Manajemen Keuangan. Edisi 13. Buku 1. Jakarta : Salemba Empat. 